\title{
23. SOUTHWEST PACIFIC CENOZOIC PALEOGEOGRAPHY AND AN INTEGRATED NEOGENE PALEOCIRCULATION MODEL
}

\author{
Anthony R. Edwards, New Zealand Geological Survey, Lower Hutt, New Zealand
}

\section{INTRODUCTION}

Our knowledge of the geological history of the southwest Pacific has recently been greatly expanded by deep-sea drilling, detailed sea-floor magnetic, and nearshore petroleum exploration studies. Although this information will take a considerable time to assimilate, it is now possible, providing several major assumptions are made, to arrive at fair approximations of the Cenozoic paleogeography of the southwest Pacific and to develop a Neogene paleocirculation model. Such reconstructions can greatly assist our understanding of the numerous geographic and stratigraphic variations evident in the lithologies and fossil contents of ancient sediments.

The inferred paleogeographies, given in terms of the ever-changing positions of continental blocks and their coastlines, are heavily dependent not only on published geophysical and geological studies, but also on major assumptions such as the presumed fixed Cenozoic positions of Antarctica and most of Indonesia. The postulated paleocirculation model, given in terms of the inferred positions of the hydrological boundaries separating major surface water masses, is dependent upon the paleogeographies. The names adopted for the water masses and their boundaries are based on their assumed ancestral relationships to the present hydrological features. Except in a very general sense, these names are not indicative of climatic zones because subsequent changes brought about by changes in paleogeography must be taken into account.

The maps presented in this report (Figures 1 to 11) are based on an oblique equidistant azimuthal projection centered at $41^{\circ} 19^{\prime} \mathrm{S}, 174^{\circ} 46^{\prime} \mathrm{E}$ (New Zealand Mapping Service Map 47, 3rd ed., 1973). This unusual projection was selected for two reasons: first, there is little visual distortion over a wide range of latitude and longitude, and second, it fortuitously allows the Cenozoic paleopositions of Australasia to be reconstructed without taking into account major changes in apparent size and shape. The map base has been modified by adding both the areas underlain by continental and "island arc" crust (stipple pattern), and the positions of the highstanding mid-oceanic ridge crests (mottled pattern). The boundary between continental and oceanic crust has been arbitrarily taken at either the base of the continental slope or, where such a slope is not prominent, at the 3000 -meter isobath.

\section{PALEOGEOGRAPHY}

\section{Paleopositions of Continental and Oceanic Crust}

About Mid Cretaceous time Antarctica was about $15^{\circ}$ from its present position. Australia and what is now the
New Zealand region were loosely attached to Antarctica. A broad Indo-Pacific deep-sea passage separated northern Australasia (including New Guinea and Timor) from most of the Indonesian region. This passage continued to widen throughout the Late Cretaceous and into the earliest part of the Paleogene. Concurrently the New Zealand region separated from the Antarctica-Australia continent. Details of this latter development are still far from clear, but the first major event appears to have been the splitting off from Australia of the Norfolk Ridge and consequent growth of the New Caledonia Basin. Then followed the concurrent separation of the Lord Howe Rise from east Australia, and of the large Campbell Plateau from near the present Ross Sea area of Antarctica. These latter events resulted in the growth probably as continuous features, of the ancestral southwest Pacific, PacificAntarctic, and Tasman basins.

In the mid Paleocene a major change occurred. The previous tectonic trends appear to have been abruptly terminated and replaced by a pattern recognizably similar to the present regime. The bonds previously loosely attaching Australia to Antarctica were broken, and Australia plus the now interlocked western part of the New Zealand subcontinent commenced to move northward. Eastern New Zealand, including the large Campbell Plateau, also moved northward, but possibly accompanied by substantial concurrent counterclockwise rotation. Major results of this new pattern were the slow growth of the now broad Australia-Antarctica deep-sea passage, the continued slow growth, probably with a modified trend (see above), of the New ZealandAntarctica deep-sea passage, and the gradual construction of the Indo-Pacific passage. The latter trend eventually resulted in the collision of northern Australasia with most of Indonesia about mid Miocene time. Numerous other as yet poorly understood developments occurred as a result of this major change in tectonic pattern. Early events include the growth of the South Fiji Basin about Eocene or Oligocene time, of the Coral Sea Basin about early Eocene time, of the New Hebrides Basin about mid Eocene time, and of the Emerald Basin in Oligocene time. Growth of the Emerald Basin appears to have ceased when the Macquarie Ridge came into being in earliest Miocene time. Subsequent events include the still actively continuing very complex disruption of most of the northern and eastern rims of the southwest Pacific marginal seas. These essentially late Neogene disruptions have resulted in the formation of many basins, notably the Pandora Basin (often called the Fiji Plateau), and the narrow but lengthy Lau and Harve basins. The latter basins appear to have resulted from the separation of the Tonga and Kermadec ridges from the Lau and Colville ridges. 


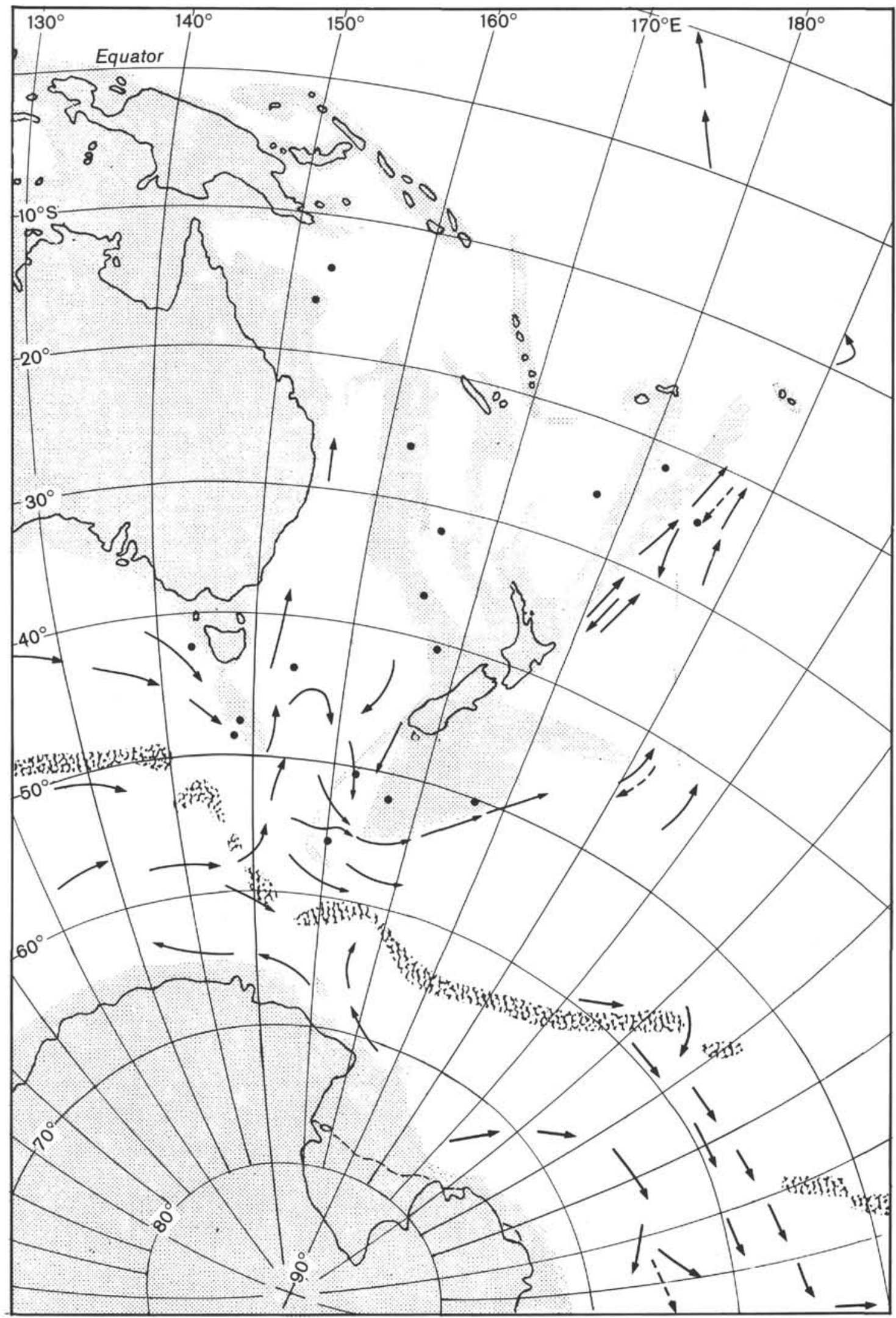

Figure 1. Present-day southwest Pacific bottom-water circulation pattern. 


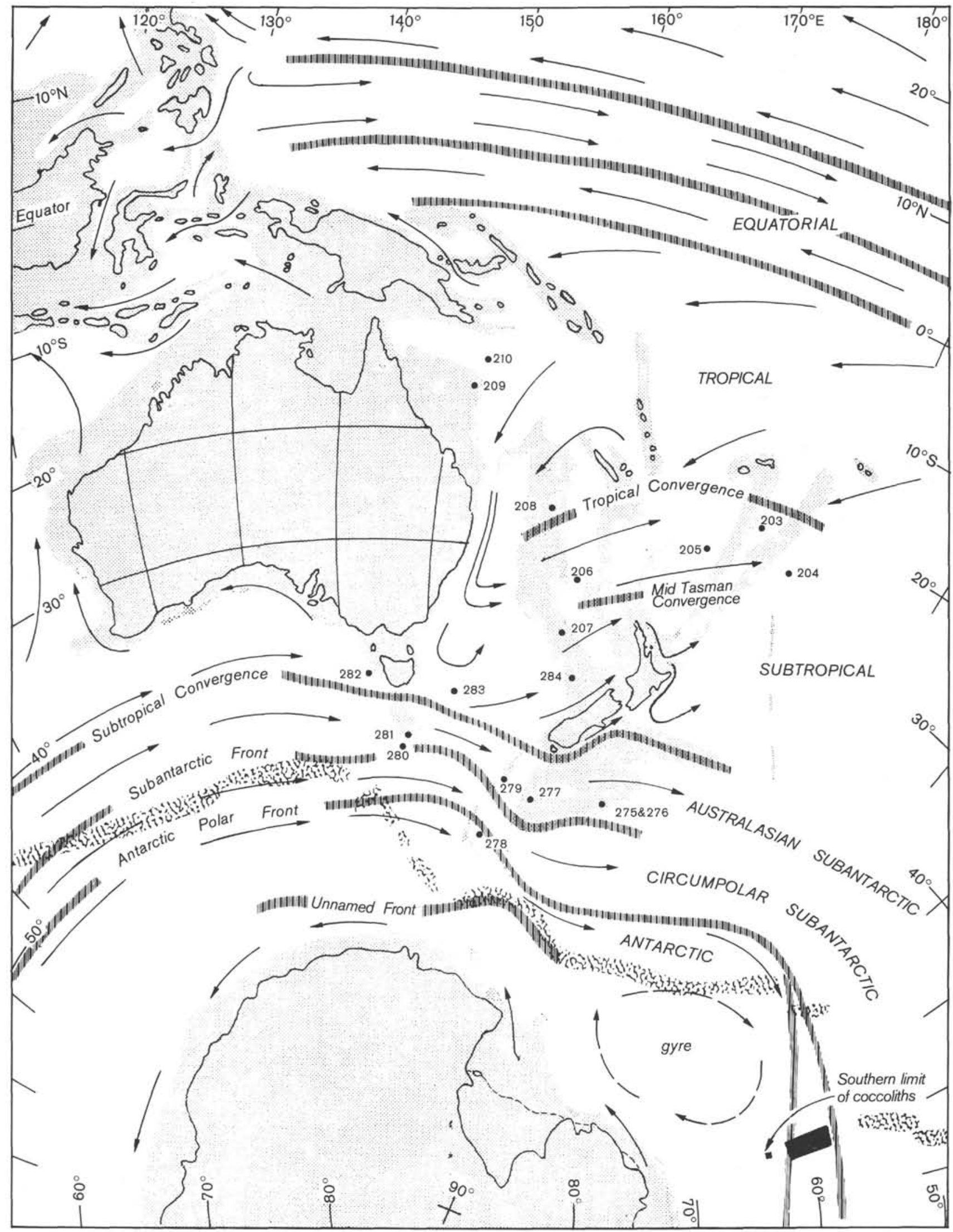

Figure 2. Present-day southwest Pacific surface-water circulation pattern (winter situation). 


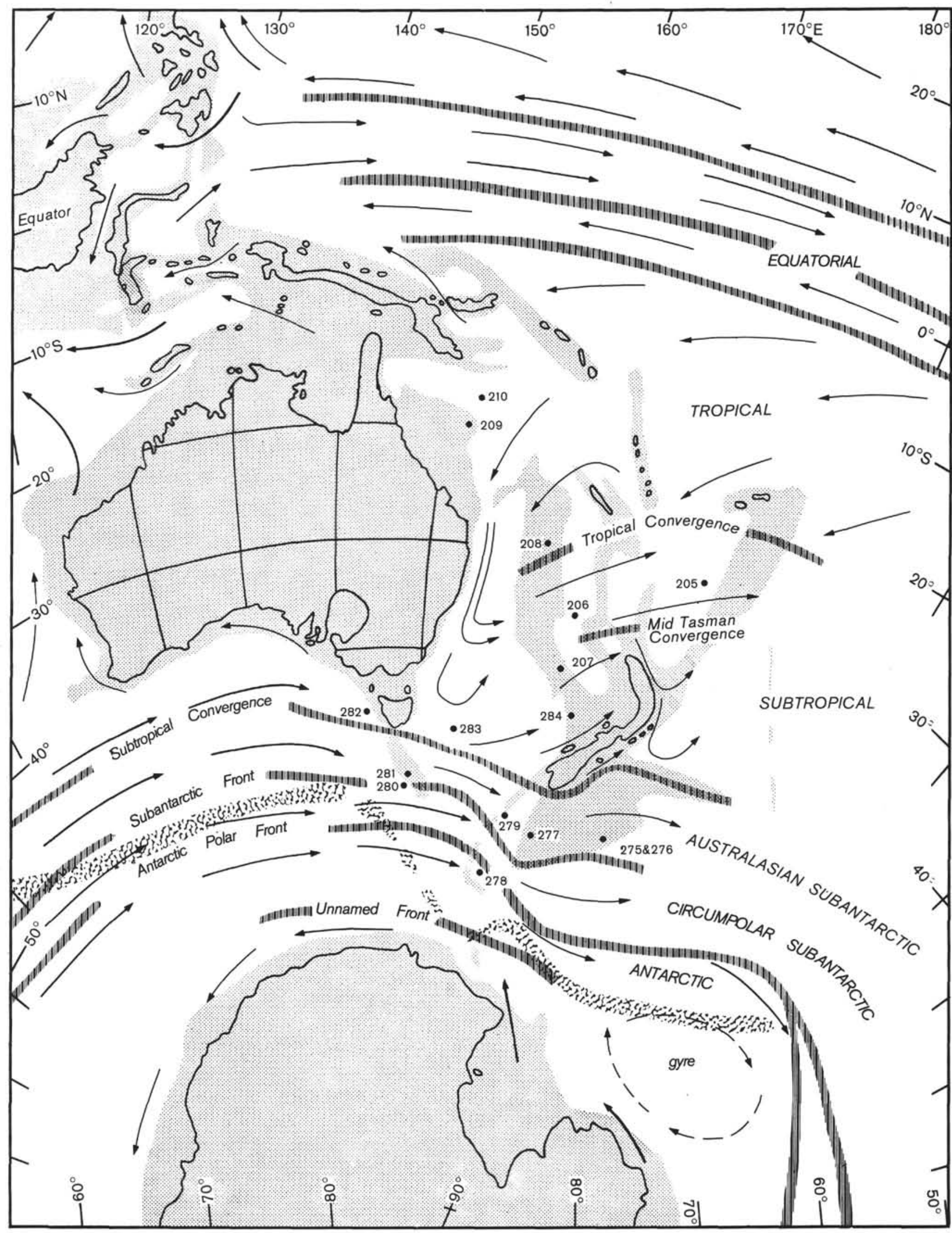

Figure 3. Late Miocene (7 m.y.) and early Pliocene southwest Pacific paleogeography and surface-water circulation pattern (winter situation). 


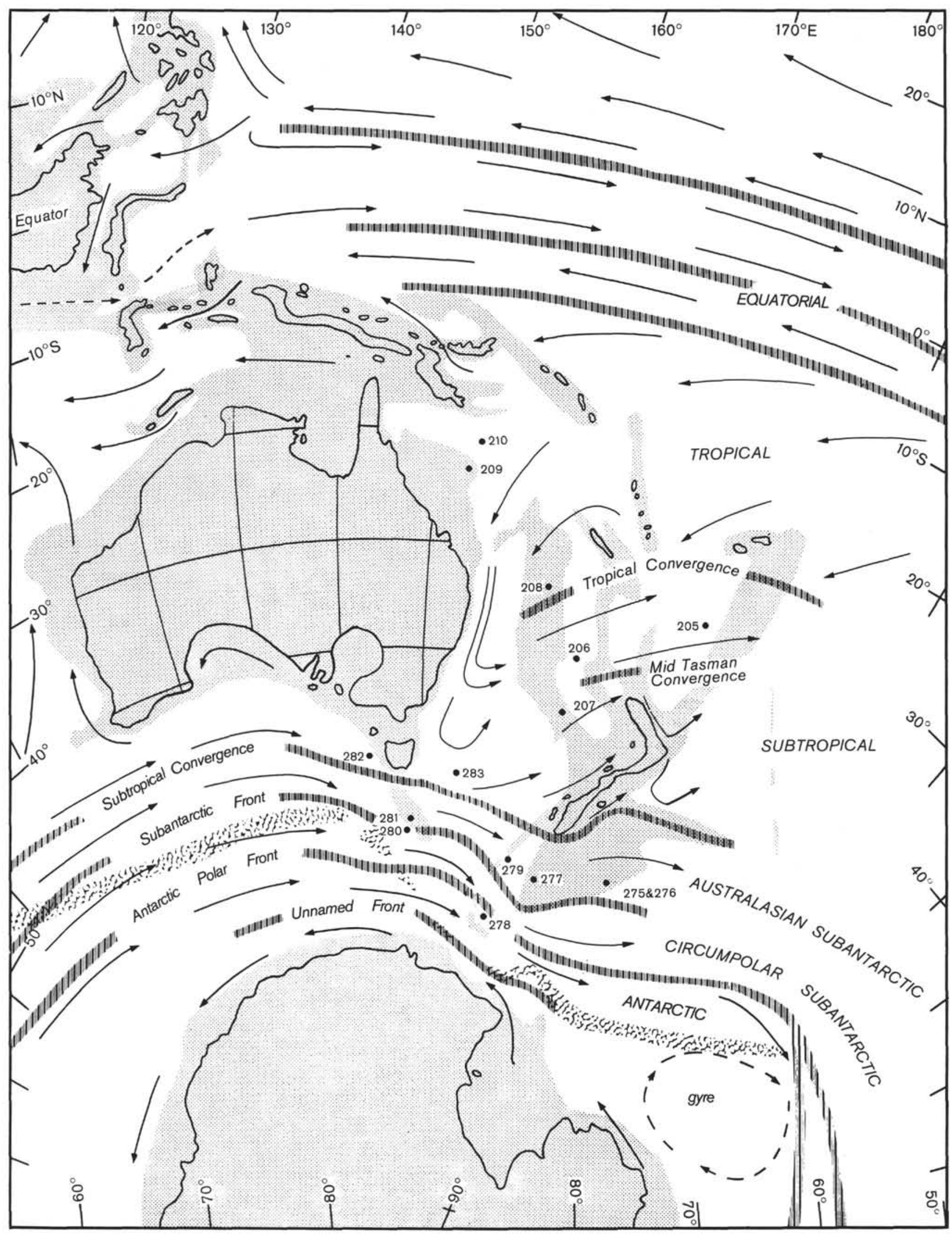

Figure 4. Mid Miocene (13 m.y.) southwest Pacific paleogeography and surface-water circulation pattern (winter situation). 
A. R. EDWARDS

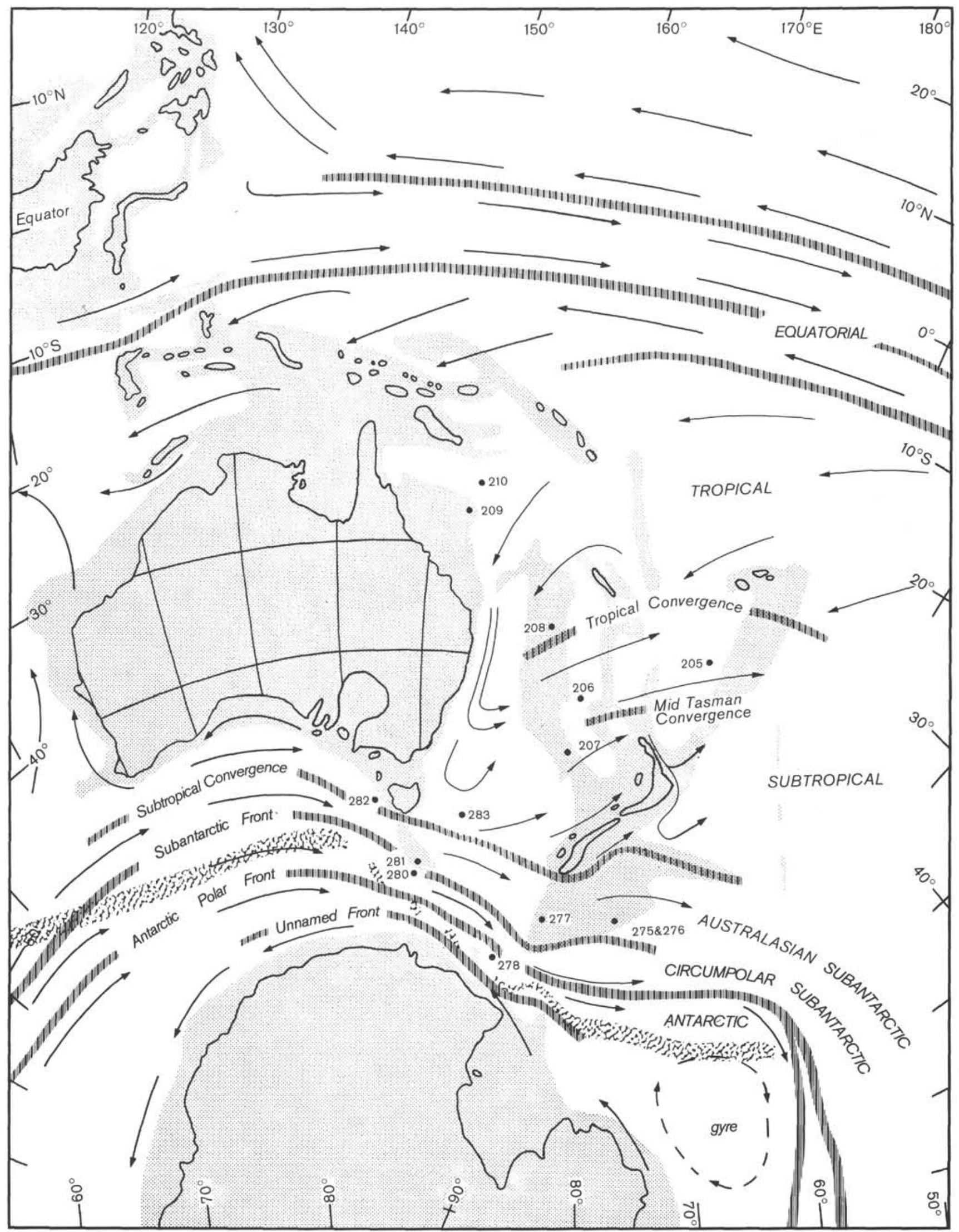

Figure 5. Early Miocene (21 my.) southwest Pacific paleogeography and surface-water circulation pattern (winter situation).

672 


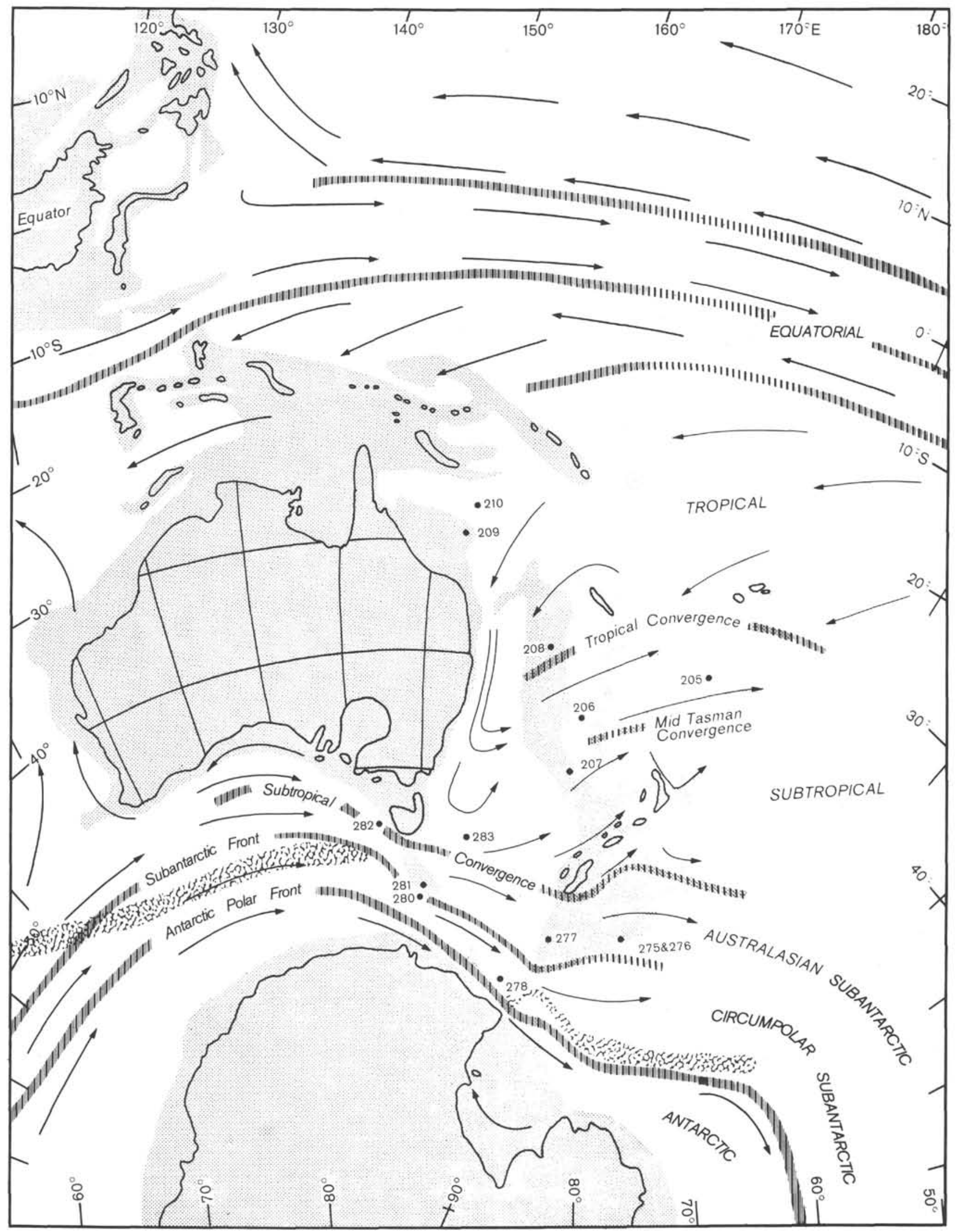

Figure 6. Late (and mid) Oligocene (27 m.y.) southwest Pacific paleogeography and surface-water circulation pattern (winter situation). 


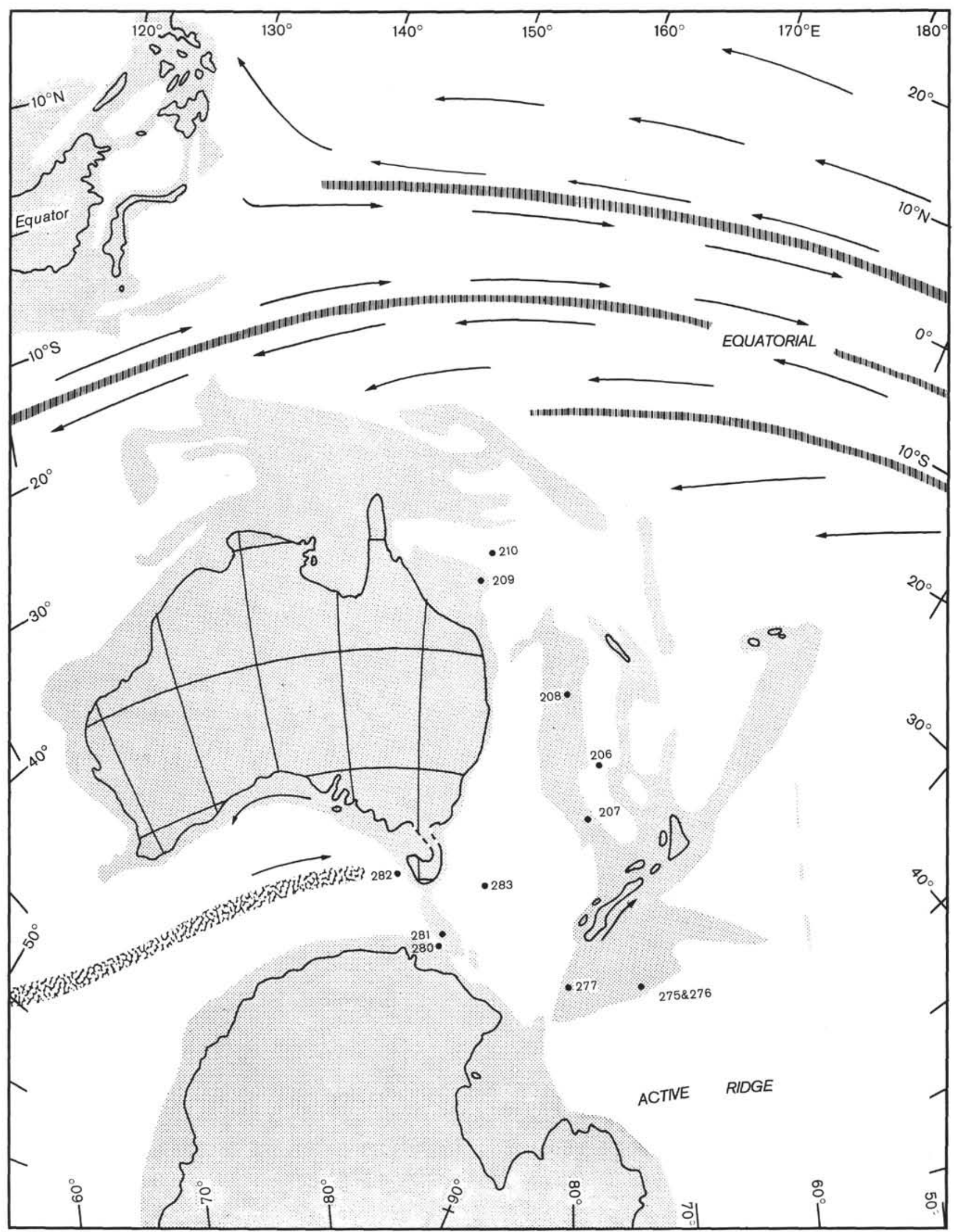

Figure 7. Early Oligocene (35 m.y.) southwest Pacific paleogeography and equatorial surface-water circulation pattern. 


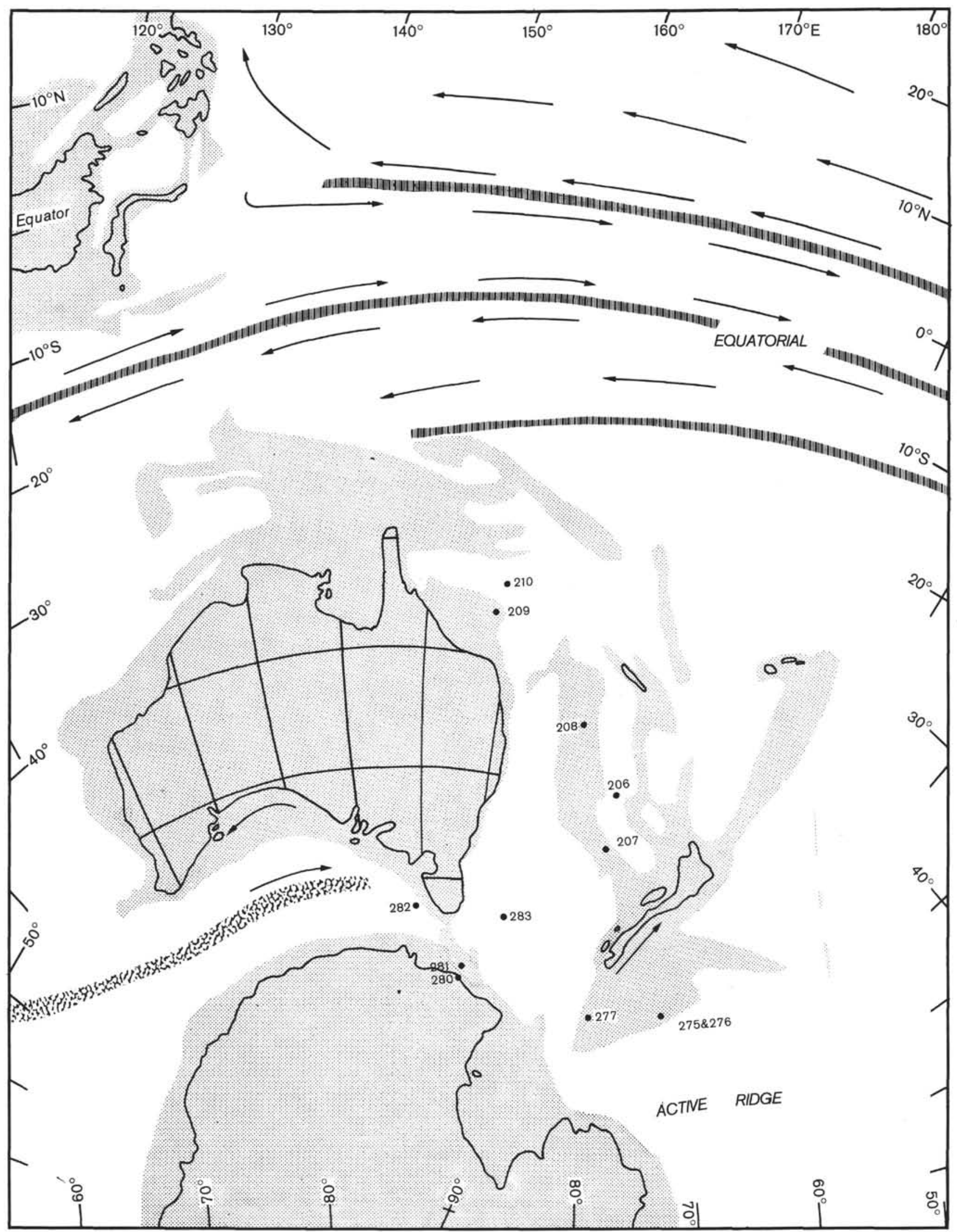

Figure 8. Late Eocene (42 m.y.) southwest Pacific paleogeography and equatorial surface-water circulation pattern. 


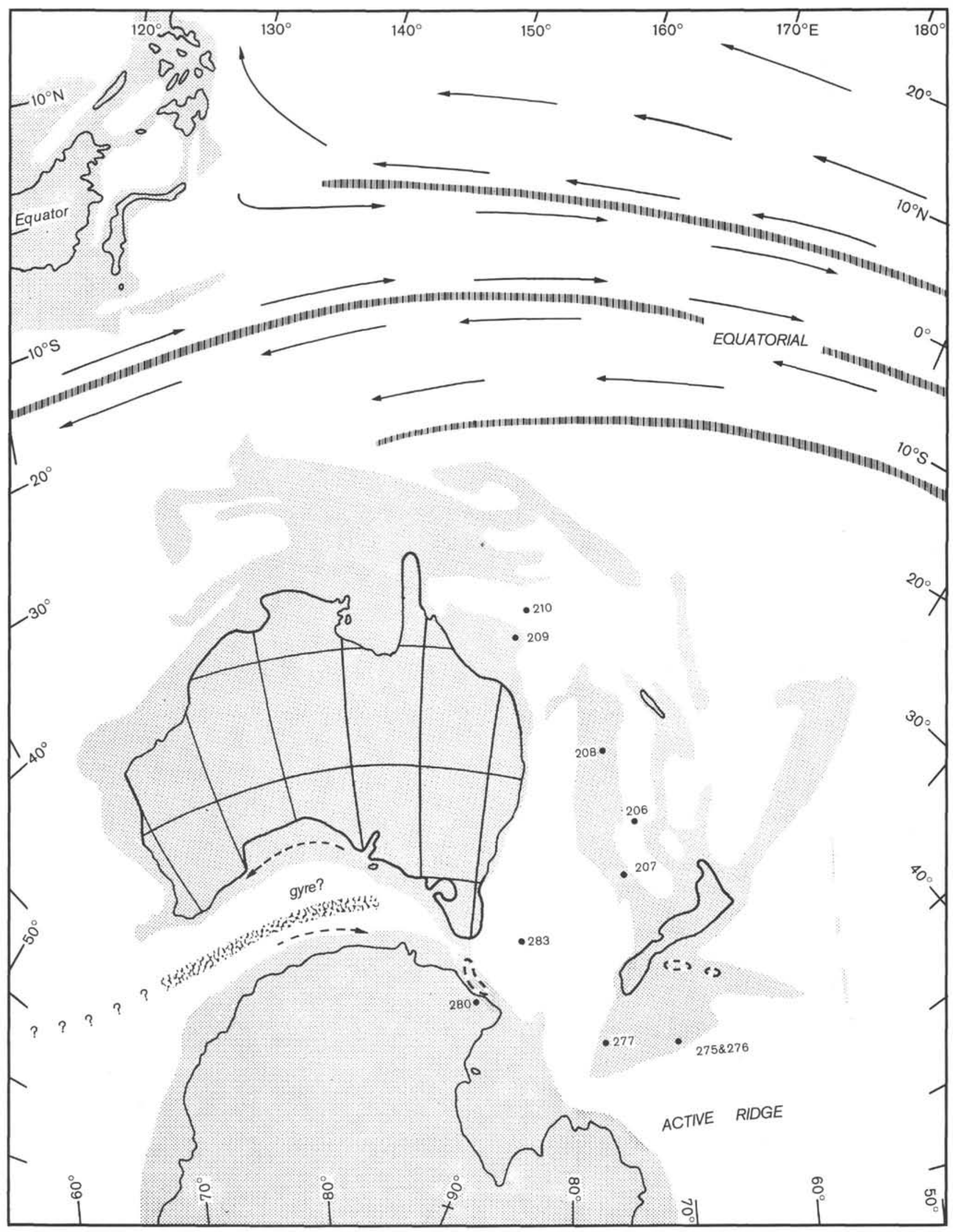

Figure 9. Mid Eocene (47 m.y.) southwest Pacific paleogeography and equatorial surface-water circulation pattern. 


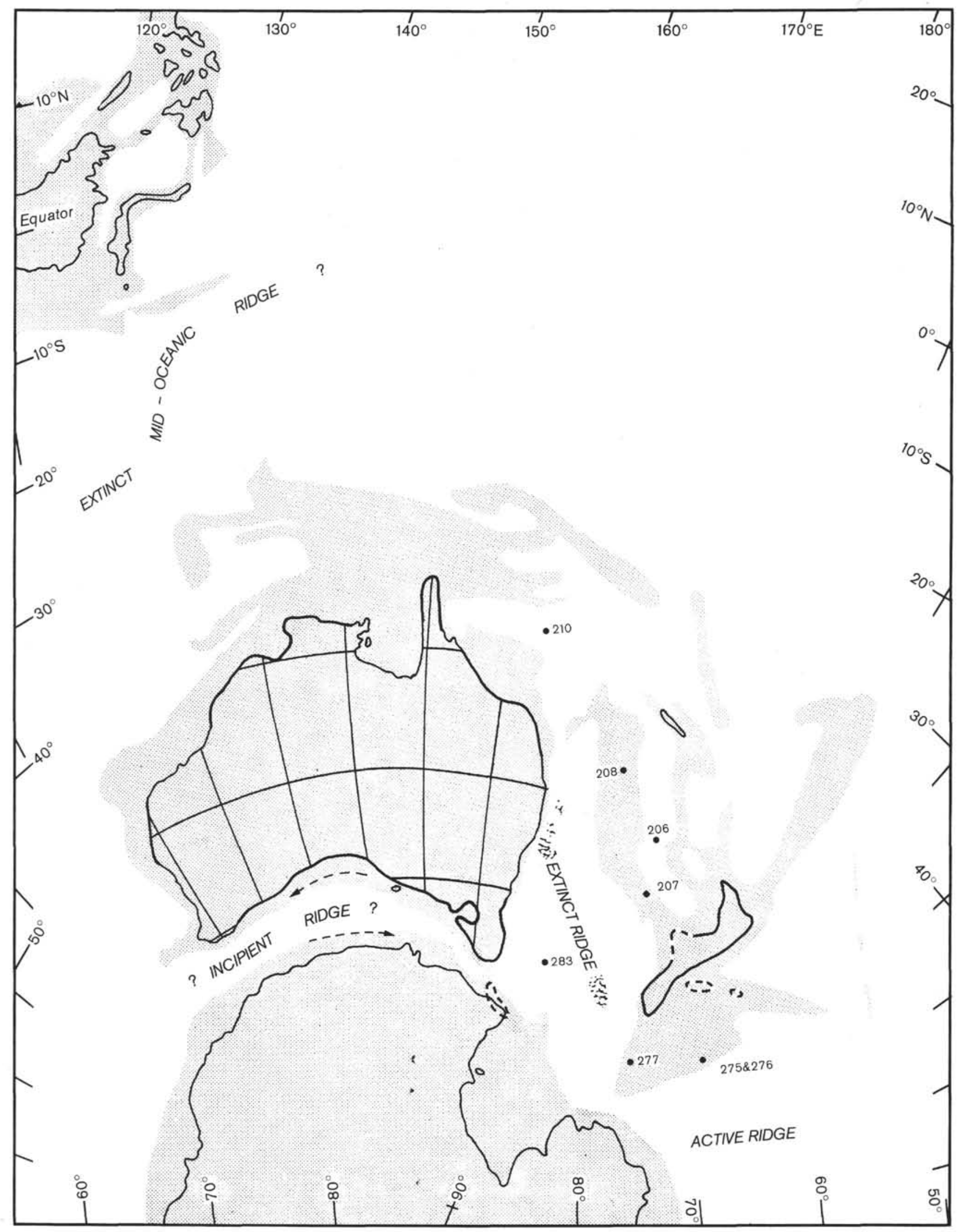

Figure 10. Early Eocene (52 m.y.) southwest Pacific paleogeography. 
A. R. EDWARDS

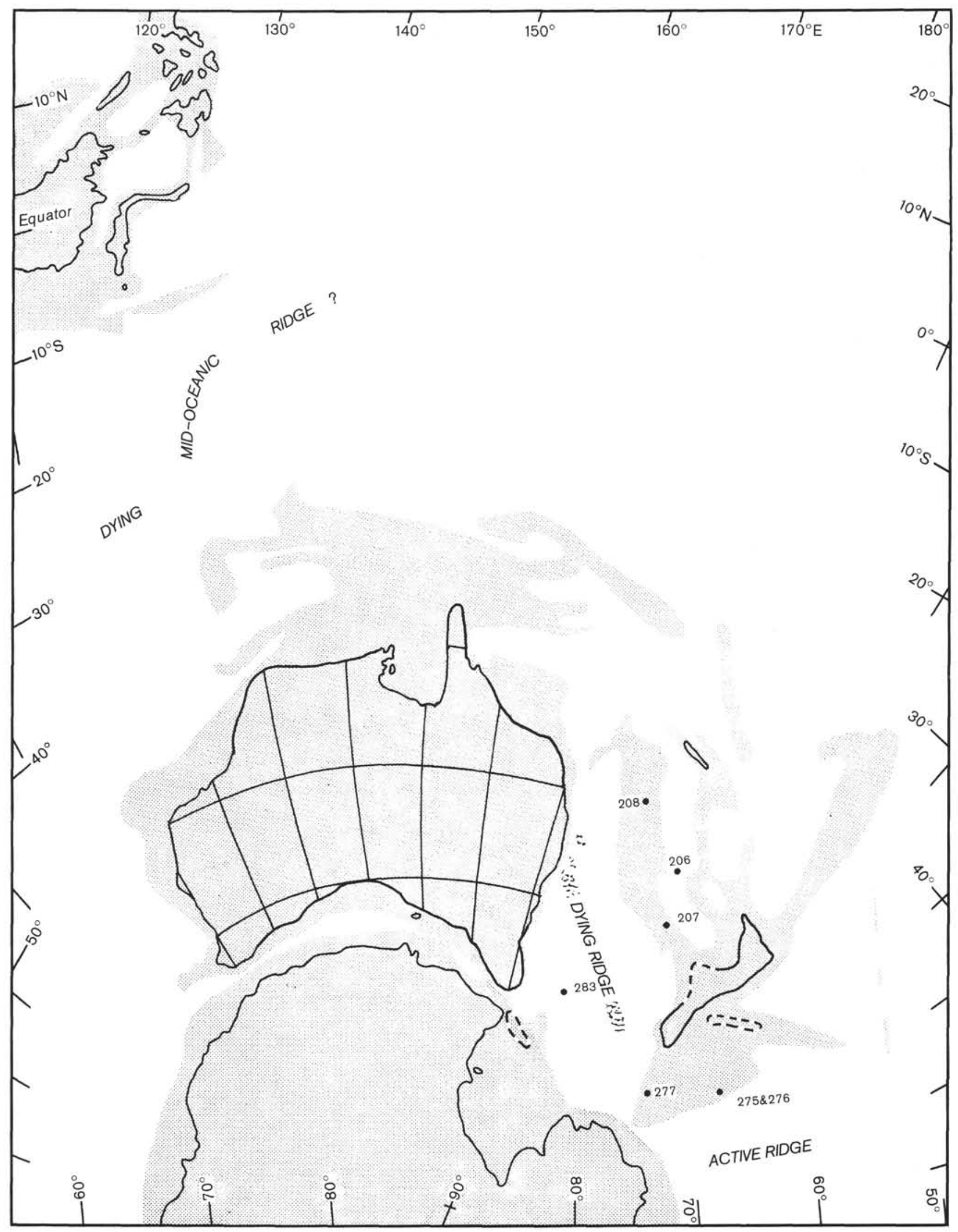

Figure 11. Mid Paleocene (58 my.) southwest Pacific paleogeography.

678 
The above account is, with one exception, based on the information presented in a wide variety of geophysical and geological papers (see Additional Selected References under the subheading Paleogeography Continental and Oceanic Crust Paleopositions). The exception relates to the formation of the New Caledonia Basin which, the writer suggests, occurred shortly prior to the formation and growth of the Tasman Basin ( 80 m.y. to 60 m.y., Hayes and Ringis, 1973). This inference is essentially based on the New Caledonia Basin having a known minimum age of early Paleocene (ca 62 m.y.) at a sampling point which, although 734 meters subbottom, is probably a considerable distance above basement (Burns, Andrews, et al., 1973). Thus, it is possible that the adjacent similarly trending New Caledonia and Tasman basins represent sequential expressions of the same tectonic trend.

The information on which the above generalized account of the tectonic history of the southwest Pacific is based can be converted into the basis for a series of paleogeographic maps provided several assumptions are made. The paleogeographies given in Figures 3 to 11 include the following arbitrary decisions. First, the seafloor spreading interpretations given by Weissel and Hayes (1972), and Hayes and Ringis (1973) for the south Australia, eastern south Indian, and Tasman basins were adopted. The similarly based interpretation given by Christoffel and Falconer (1972) for the southwest Pacific Basin adjacent to the Campbell Plateau, was not used because of inadequate information about the tectonic effects within and near New Zealand-for example, see the discussion in Scholz et al. (1973) regarding the timing, sense, and extent of Alpine Fault movement. Second, it was assumed that the present positions and orientations of Antarctica and Indonesia were acquired prior to the Cenozoic. Although almost certainly only approximations to reality, these assumptions are fairly consistent with the interpretations given by AudleyCharles et al. (1972), Falvey (1972), Hamilton (1971), Heirtzler et al. (1973), and McElhinny and Embleton (1974). Furthermore, these assumptions conveniently allow the paleogeographies to be stated in terms of present-day geographic coordinates. Third, because of inadequate information, no attempt was made to reconstruct either the growth of the Coral Sea, Emerald, New Hebrides, South Fiji, and numerous Melanesian basins, or the very complicated pattern of Cenozoic faulting which has undoubtedly occurred within, and especially around the rim of, the southwest Pacific marginal seas. The decision not to move the Alpine Fault and allied faults of New Zealand during the Cenozoic has already been mentioned. Also, no attempt was made to realistically portray the complexities caused by the collision between northern Australasia (including Timor and New Guinea) and most of Indonesia-for example, see Audley-Charles et al. (1972) and Hamilton (1971). Consequently, the much oversimplified paleogeography employed results in part of present-day southeastern Indonesia appearing to override the mid Miocene Lesser Sundra Islands (Sigit, 1962). Despite the above severe limitations, the writer feels that the results obtained are worth considering when attempting to reconstruct paleoenvironments.

\section{Coastline Paleopositions}

The coastlines given in Figures 3 to 11 were modified from their present positions by compilation of the data and opinions in the papers listed in the Additional Selected References under the subheading Paleogeography (Coastline Paleopositions). The ages given in these papers were usually accepted at face value. However, wherever possible updated age assignments were made by utilizing the correlation data given in Hornibrook and Edwards (1971) and Ludbrook and Linsay (1967). Even so the coastline positions given are coarse approximations to the actual situation for two reasons. First, they are based on correlations with subdivisions of epochs, whereas the positions of the continental crust areas are based on correlations with the "absolute" time scale. Second, the accuracy of the correlations varies greatly.

The coastlines of Antarctica, the Gulf of Carpentaria (northern Australia), New Caledonia, and most of the Indonesia-Malyasia-Philippines region have not been modified from their present positions due to a lack of information. However, preliminary results from DSDP Leg 28 (Hayes, Frakes, et al., 1973) indicate that the Ross Sea has existed throughout the Neogene. For cartographic clarity the Indonesian Lesser Sundra Islands are shown as being submerged throughout the late Miocene to mid Paleocene interval. Upon "backtracking" the numerous Melanesian islands, their coastlines were left unmodified back to the oldest indication of tuffaceous sediments on the island, or an adjacent island. (Geological Map of the World, Australia and Oceania, Sheets 7, 1965, and 8, 1967). Beyond this, their coastlines were deleted from the maps. Another arbitrary decision was made to delete all of the coastlines of the islands northwest of Australia and south of "fixed" Indonesia from Figures 7 to 11. In Figures 3 to 6 these coastlines are, for lack of information to the contrary, shown in their present form.

\section{PALEOCIRCULATION}

\section{Introduction}

The inferred present-day southwest Pacific bottom current and winter surface water circulation patterns (Figures 1 and 2) have been compiled or interpreted from the physical oceanography and marine geology papers listed in the Additional Selected References under the subheadings Paleocirculation (Bottom Waters) and Paleocirculation (Surface Waters), respectively, The present-day bottom water circulation pattern is, as might be expected, strongly influenced by the distribution of passages between the various deep-sea basins. This is expecially true of those passages which allow significant eastward or northward movements, for example, the passages within and south of the northsouth-trending Macquarie Ridge (Gordon, 1972). Likewise, the present-day positions of the currents and hydrological fronts forming the boundaries of surface water masses are strongly influenced by: (1) the coastline positions and (2) the shapes and positions of highstanding bathymetric features. These constraints are particularly evident in the relatively high latitude fronts (Figure 2). 
In view of the above, it seems reasonable to "backtrack" the present-day hydrological features into the past by using "best possible fit" to the paleogeography. The validity of this method of reconstructing past circulation patterns is dependent on the assumption that the influence of the mean wind field on the pattern is subservient to that produced by paleogeographic changes (see discussion in Zillman, 1972, p. 34-35). Another fundamental assumption made here is that the present-day water masses and other hydrological features represent only a momentary evolutionary stage in the continuing development of the overall pattern. This concept is similar to that put forward by Vella (1973). It implies that the overall range, mean, and gradient distribution of each of the parameters by which the present-day water masses are distinguished have also undergone changes of an evolutionary nature. Thus, for example, the present mean temperature range of the southern part of the Subtropical water mass may once have been typical of the ancestral Australasian Subantarctic water mass (despite both water masses then having a higher latitude of occurrence than today). Furthermore, since no water mass is completely isolated from the others, it follows that modification of the nature of one water mass must, sooner or later, cause at least minor changes to occur in all. But the basic pattern of water masses and their hydrological boundaries will tend to persist for long periods of time because all changes, whether small or large, must be compatible with the physical constraints provided by the only very slowly changing paleogeography and its derivative climate. Thus we have a complex, and constantly adjusting, feedback mechanism involving modifications in circulation, climate, and geography which ultimately result from sea-floor spreading.

\section{Bottom Waters}

The inferred present-day circulation pattern (Figure 1) shows three main features: (1) eastward and westward moving flows (of Antarctic Bottom Water) originating near the base of the Ross Sea continental slope, (2) a broad and intense eastward moving flow with eddies in the southern part of the Tasman Basin (Antarctic Circumpolar Current), and (3) a narrow but intense northward-moving flow along the western margin of the deep Southwest Pacific Basin (Western Boundary Undercurrent). The significant northward flow occurring within the northern part of the Tasman Basin probably represents another Western Boundary Undercurrent. Bottom water movement in the New Caledonia Basin, which is not open to the south, is negligible. The South Fiji Basin may receive some Western Boundary Undercurrent water via a gap in the sill just north of New Zealand. The present axis of the intense Antarctic Circumpolar Current often coincides with vast areas of manganese pavement and associated sediment erosion, winnowing or nondeposition. Likewise, the Western Boundary Undercurrent usually coincides with large areas of sediment erosion or nondeposition. In contrast, the Antarctic Bottom Water occurring south of the mid-oceanic ridge is associated with thick fine-grained detrital sediments.

Kennett, Houtz, et al., (1975) have provided substantial evidence that the Antarctic Circumpolar Current, the dominant component of the present-day deep-sea circulation pattern, came into existence about late Oligocene time as a result of the growth of a deep-sea passage separating the South Tasman Rise from east Antarctica (cf. Figures 1, 6, and 7). The widespread erosion or nondeposition of latest Eocene sediments in the Tasman and Coral sea areas (Edwards, 1973) was attributed to the initiation of Antarctic Bottom Water production as a result of the onset of substantial glaciation of Antarctica. Although this may well have been the cause (cf. Figure 8) another explanation is suggested. Using mathematical models, Gill and Bryan (1971) have demonstrated that a Southern Ocean probably requires both a northward-moving Western Boundary Undercurrent and its southward-moving surface counterpart (for example, the East Australian Current) regardless of whether a circumpolar current was present or absent. Thus, it seems likely that Eocene deposition in the Coral and Tasman sea areas was in equilibrium with both a Western Boundary Undercurrent and an East Australian Current. It is suggested that this situation was disturbed, with consequent regional erosion and nondeposition, in latest Eocene time by a reorganization of the South Pacific Ocean circulation brought by the initiation of circumpolar current flow (across the shallow South Tasman Rise) and concurrent opening of Drakes Passage-a mid Tertiary event according to Barker (1970). Such a sequence of events would almost certainly result in a substantial cooling of Antarctica. However, it is suggested that full-scale glaciation of Antarctica, and the consequent production of erosive Antarctic Bottom Water in significant amounts, could not occur until an intense circumpolar current involving the movement of both surface and bottom waters came into being. Comparison with both the inferred paleogeographies and the results obtained by DSDP Leg 29 (Kennett, Houtz, et al., 1975) suggests that this situation commenced to form in mid Oligocene time and reached maturity about earliest Miocene time. In all probability the basic development of the present-day surface circulation pattern also occurred within this same interval of time (see below).

The above hypothesis has the advantages of utilizing specific deep-sea and surface currents, together with the associated oceanic turnover, to form the southwest Pacific regional Eocene-Oligocene unconformity and thus of providing an explanation of its distribution. For example, the unconformity's apparent presence in relatively shallow water sequences along the eastern margin of Australia, but its absence in comparable New Zealand sequences, is probably a result of the distribution of the ancestral East Australian Current. Furthermore, this hypothesis goes a long way towards explaining why the time taken before permanent deposition recommenced varies so much from sequence to sequence. At most localities the regional unconformity would have have resulted not only from the initial latest Eocene water circulation reorganization but also from the subsequent mid to late Oligocene reorganization which, at high latitudes, produced a separate feature. The distinction between these two events is most clearly seen in the South Tasman Rise Site 281 sequence (Kennett, Houtz, et al., 1975). Admitted weaknesses in this hypothesis are the unproven latest Eocene age 
assumed for the Drakes Passage opening and the apparent narrowness at that time of the deep-sea gap between the Campbell Plateau and west Antarctica. However, the latter objection may be invalid (see above under Paleogeography).

Comparison with the "lagoonal" versus "estuarine" thesis of Berger (1970) suggests that the opening of the South America-Antarctica and Australia-Antarctica gaps probably resulted in substantial changes to the water chemistry of the southern oceans. These changes may, for example, greatly complicate our understanding and interpretation of the oxygen isotope ratios obtained from fossil sediments. Finally, it is commented that the semi-enclosed nature of the Australia-Antarctica and Tasman seas during the early Cenozoic suggests that circulation in their deeper parts may have been sluggish-a conclusion fully consistent with the results obtained by DSDP Leg 29 (Kennett, Houtz, et al., 1975).

\section{Surface Waters}

The two major changes evident in the inferred surface-water circulation patterns are:

1) The present-day pattern of high-latitude circulation cannot be "back-tracked" much beyond the Neogene due to progessive constriction of the AustraliaAntarctica gap. Although the late Oligocene paleogeography (Figure 6) indicates a gap twice the width of the present-day Drakes Passage, the width of the deepwater channel appears to have been less than half as wide as Drakes Passage is today. For this reason the late Oligocene paleocirculation does not show the gyre and unnamed front given on all of the Neogene maps, and the Antarctic Polar Front has been drawn as occurring entirely south of the mid-oceanic ridge. If the writer's assumption is correct, the climate of Antarctica may have undergone a substantial deterioration across the Oligocene-Miocene boundary. In contrast, the climate of southern Australasia (except Site 278) appears to have undergone a significant amelioration across the Oligocene-Miocene boundary (see Edwards and PerchNielsen, in Kennett, Houtz, et al., 1975). These two apparently contradictory situations may have resulted from an increase in the latitudinal thermal gradient across the Oligocene-Miocene boundary.

2) Substantial interchange between the equatorial waters of the Indian and Pacific oceans was probably possible as late as the early Miocene. A circulation pattern dominated by the equatorial currents would almost certainly have had a different latitudinal thermal gradient to that occurring under a circumpolar current dominated circulation pattern. Comparison with Figures 3 to 11 suggests that the former pattern occurred in the southwest Pacific during Paleocene and Eocene time and the latter pattern during all of the Neogene.

The absence of a circumpolar current in the Eocene and Paleocene probably resulted in the South Pacific circulation pattern having a much greater resemblance to the present-day North Pacific circulation pattern than occurs at present. But, apart from the equatorial water masses, no attempt to portray the pre-mid Oligocene circulation pattern was made because of the difficulty of knowing where the common boundary between the midand high-latitude gyres was relative to the paleogeography. However, the unusual southwest Pacific distribution of siliceous microfossil-rich sediments (see Burns, Andrews, et al., 1973) suggests that a hydrological feature occurred just north of New Zealand in the mid Eocene. Furthermore, from general paleogeographic considerations and the known shallow water distribution of major sheets of Eocene and Oligocene polyzoan limestones, the writer has tentatively inferred the presence of a northward-flowing current off the east coast of southern New Zealand (cf. Vella, 1973), and of a westward-flowing current in the Great Australian Bight.

\section{ACKNOWLEDGMENTS}

The writer gratefully thanks his shipboard and shorelaboratory colleagues-especially J.P. Kennett (University of Rhode Island), N.deB. Hornibrook (New Zealand Geological Survey), B.R. Stanton (New Zealand Oceanographic Institute), and A.E. Gilmour (New Zealand Oceanographic Institute), for many useful discussions. Thanks are also due to G.R. Stevens and R.P. Suggate (New Zealand Geological Survey) for permission to use their paleogeographic maps awaiting publication in The Geology of New Zealand. However, the writer accepts full responsibility for all the interpretations and opinions given in this work.

\section{REFERENCES}

Audley-Charles, M.G., Carter, D.J., and Milsom, J.S., 1972. Tectonic development of eastern Indonesia in relation to Gondwanaland dispersal: Nature Phys. Sci., v. 239, p. 3539.

Barker, P.F., 1970. Plate tectonics of the Scotia Sea region: Nature, v. 228, p. 1293-1296.

Berger, W.H., 1970. Biogenous deep-sea sediments: fractionation by deep-sea circulation: Geol. Soc. Am. Bull., v. 81, p. 1385-1402.

Burns, R.E., Andrews, J.E., et al., 1973. Initial Reports of the Deep Sea Drilling Project, Volume 21: Washington (U.S. Government Printing Office).

Christoffel, D.A. and Falconer, R.K.H., 1972. Marine magnetic measurements in the southwest Pacific Ocean and the identification of new tectonic features: Antarctic Res. Ser. 19 (Antarctic Oceanology II: The Australian-New Zealand Sector), p. 197-209.

Edwards, A.R., 1973. Southwest Pacific regional unconformities encountered during Leg 21. In Burns, R.E., Andrews, J.E., et al., Initial Reports of the Deep Sea Drilling Project, Volume 21: Washington (U.S. Government Printing Office), p. 701-720.

Falvey, D.A., 1972. Sea-floor spreading in the Wharton Basin (Northeast Indian Ocean) and the breakup of eastern Gondwanaland: APEA J., v. 12, p. 86-88.

Gill, A.E. and Bryan, K., 1971. Effects of geometry on the circulation of a three-dimensional southern-hemisphere ocean model: Deep-Sea Res., v. 18, p. 685-721.

Gordon, A.L., 1972. On the interaction of the Antarctic Circumpolar Current and the Macquarie Ridge: Antarctic Res. Ser. 19 (Antarctic Oceanology II: The AustralianNew Zealand Sector), p. 71-78.

Hamilton, W., 1971. Plate-tectonic evolution of Indonesia: Geol. Soc. Am. Abstracts with Programs, v. 3, p. 589-590. 
Hayes, D.E. and Ringis, J., 1973. Seafloor spreading in the Tasman Sea: Nature, v. 243, p. 454-458.

Hayes, D.E., Frakes, L.A. Barrett, P., Burns, D., Chen, PeiHsin, Ford, A.B., Kaneps, A.G., Kemp, E.M., McCollum, D.W., Piper, D.J.W., Wall, R.E., and Webb, P.N., 1973. Leg 28 deep-sea drilling in the southern ocean: Geotimes, v. 18, p. 19-23.

Heirtzler, J.R., Veevers, J.V., Bolli, H.M., Carter, A.N., Cook, P.J., Krasheninnikov, V.A., McKnight, B.K., Proto-Decima, F., Renz, G.W., Robinson, P.T., Rocker, K., and Thayer, P.A., 1973. Age of the floor of the eastern Indian Ocean: Science, v. 180, p. 952-954.

Hornibrook, N.deB. and Edwards, A.R., 1971. Integrated planktonic foraminiferal and calcareous nannoplankton datum levels in the New Zealand Cenozoic: Plankt. Conf., Second Proc., In Farinacci, A. (Ed.), Roma 1970 (Tecnoscumza), p. 649-657.

Kennett, J.P., Houtz, R.E., et al., 1945. Initial Reports of the Deep Sea Drilling Project, Volume 29: Washington (U.S. Government Printing Office).

Ludbrook, N.H. and Linsay, J.M., 1967. Tertiary foraminiferal zones in South Australia: Internat. Conf. Plankt. Microfossils, v. 2, p. 366-374.

McElhinny, M.W. and Embleton, B.J.J., 1974. Australian paleomagnetism and the Phanerozoic plate tectonics of eastern Gondwanaland: Tectonophysics, v. 22, p. 1-29.

Scholz, C.H., Rynn, J.M.W., Weed, R.W., and Frohlich, C., 1973. Detailed seismicity of the Alpine Fault Zone and Fiordland Region, New Zealand: Geol. Soc. Am., v. 84, p. 3297-3316.

Sigit, S., 1962. A brief outline of the geology of the Indonesian Archipelago: Indonesia Djawatan Geologi, Peta Geologi Indonesia 1:5,000,000.

Weissel, J.K. and Hayes, D.E., 1972. Magnetic anomalies in the southeast Indian Ocean: Antarctic Res. Ser. 19 (Antarctic Oceanology II: The Australian-New Zealand Sector), p. 165-196.

Vella, P., 1973. Ocean paleotemperatures and oscillations of the Subtropical Convergence zone on the eastern side of New Zealand. In Fraser, R. (Ed.), Oceanography of the South Pacific 1972: Wellington (New Zealand National Commission for UNESCO), p. 315-318.

Zillman, J.W., 1972. Solar radiation and sea-air interaction south of Australia: Antarctic Res. Ser. 19 (Antarctic Oceanology II, The Australian-New Zealand Sector), p. 1140.

\section{ADDITIONAL SELECTED REFERENCES}

\section{Paleogeography (Continental and Oceanic Crust Paleopositions)}

Andrews, J.E., Packham, G.H., Eade, J.V., Holdsworth, B.K., Jones, D.L., Klein, G. de-V., Kroenke, L.W., Saito, T., Shafik, S., Stoeser, D.B. and Van der Lingen, G.J., 1973. Southwest Pacific structures: Geotimes, v. 18, p. 1821.

Audley-Charles, M.G., Carter, D.J., and Milsom, J.S., 1972. Tectonic development of eastern Indonesia in relation to Gondwanaland dispersal: Nature Phys. Sci., v. 239, p. 3539.

Burns, R.E., Andrews, J.E., Van der Lingen, G.J., Churkin, M., Galehouse, J.S., Packham, G.H., Davies, T.A., Kennett, J.P., Dumitrica, P., Edwards, A.R., and Von Herzen, R.P., 1973. Initial Reports of the Deep Sea Drilling Project, Volume 21: Washington (U.S. Government Printing Office).

Christoffel, D.A. and Falconer, R.K.H., 1972. Marine magnetic measurements in the southwest Pacific Ocean and the identification of new tectonic features: Antarctic Res.
Ser. 19 (Antarctic Oceanology II: The Australian-New Zealand Sector, p. 197-209.

Edwards, A.R., 1973. Calcareous Nannofossils from the Southwest Pacific, Deep Sea Drilling Project, Leg 21. In Burns, R.E., Andrews, J.E., et al., Initial Reports of the Deep Sea Drilling Project, Volume 21: Washington (U.S. Government Printing Office), p. 641-691.

Falvey, D.A., 1972. Sea-floor spreading in the Wharton Basin (Northeast Indian Ocean) and the breakup of eastern Gondwanaland: APEA J., v. 12, p. 86-88.

Hamilton, W., 1971. Plate-tectonic evolution of Indonesia: Geol. Soc. Am. Abstracts with Programs, v. 3, p. 589-590.

Hayes, D.E. and Ringis, J., 1973. Seafloor spreading in the Tasman Sea: Nature, v. 243, p. 454-458.

Heirtzler, J.R., Veevers, J.V., Bolli, H.M., Carter, A.N., Cook, P.J., Krasheninnikov, V.A., McKnight, B.K., Proto-Decima, F., Renz, G.W., Robinson, P.T., Rocker, K., and Thayer, P.A., 1973. Age of the floor of the eastern Indian Ocean: Science, v. 180, p. 952-954.

Herron, E.M., 1971. Crustal plates and sea floor spreading in the southeastern Pacific: Antarctic Res. Ser. 15 (Antarctic Oceanology I), p. 229-237.

Johnson, T. and Molnar, P., 1972. Focal mechanisms and plate tectonics of the southwest Pacific: J. Geophys, Res., v. 77 , p. $5000-5032$.

Karig, D.E., 1970. Ridges and basins of the Tonga-Kermadec island arc system: J. Geophys. Res., v. 75, p. 239.

MacDonald, K.C., Luyendyk, B.P., and Von Herzen, R.P., 1973. Heat flow and plate boundaries in Melanesia: J. Geophys. Res., v. 78, p. 2537-2546.

McElhinny, M.W. and Embleton, B.J.J., 1974. Australian paleomagnetism and the Phanerozoic plate tectonics of eastern Gondwanaland: Tectonophysics, v. 22, p. 1-29.

Scholz, C.H., Rynn, J.M.W., Weed, R.W., and Frohlich, C., 1973. Detailed seismicity of the Alpine Fault Zone and Fiordland Region, New Zealand: Geol. Soc. Am., v. 84, p. 3297-3316.

Sclater, J.S., Hawkins, J.W., Mammerickx, J., and Chase, C.G., 1972. Crustal extension between the Tonga and Lau ridges: petrologic and geophysical evidence: Geol. Soc. Am. Bull., v. 83, p. 505-518.

Sigit, S., 1962. A brief outline of the geology of the Indonesian Archipelago: Indonesia Djawatan Geologi, Peta Geologi Indonesia 1:5,000,000.

Weissel, J.K. and Hayes, D.E., 1972. Magnetic anomalies in the southeast Indian Ocean: Antarctic Res. Ser. 19 (Antarctic Oceanology II: The Australian-New Zealand Sector), p. 165-196.

\section{Paleogeography (Coastline Positions)}

Burns, R.E., Andrews, J.E., et al., 1973. Initial Reports of the Deep Sea Drilling Project, Volume 21: Washington (U.S. Government Printing Office).

Condon, M.A., 1965. The geology of the Carnarvon Basin, Western Australia. Part 1: Pre-Permian stratigraphy: Australian Bur. Min. Resources, Geol. Geophys. Bull., v. 77.

1968. The geology of the Carnarvon Basin, Western Australia. Part 3: Post-Permian stratigraphy; structure; economic geology; Australian Bur. Min Resources, Geol. Geophys. Bull., v. 77.

Condon, M.A., Johnstone, D., Prichard, C.E., and Johnstone, M.H., 1956. The Giralia and Marrilla Anticlines, Northwest Division, Western Australia: Australian Bur. Min. Resources, Geol. Geophys. Bull. 25.

Davies, H.L. and Smith, I.E., 1971. Geology of eastern Papua: Geol. Soc. Am. Bull., v. 82, p. 3299-3312.

Elliot, J.L., 1972. Continental drift and basin development in southeastern Australia: APEA J., v. 12, p. 46-51. 
Gill, E.D., 1973. Geology and geomorphology of the Murray River Region between Mildura and Renmark, Australia: Mem. Nat. Mus. Victoria 34, p. 1-97.

Harrison, J., 1969. A Review of the sedimentary history of the island of New Guinea: APEA J., v. 9., p. 41-48.

Hayes, D.E., Frakes, L.A., Barrett, P., Burns, D., Chen, PeiHsin, Ford, A.B., Kanaps, A.G., Kemp, E.M., McCollum, D.W., Piper, D.J.W., Wall, R.E., and Webb, P.N., 1973. Leg 28 deep-sea drilling in the southern ocean: Geotimes, v. 18 , p. $19-23$.

Hornibrook, N.deB. and Edwards, A.R., 1971. Integrated planktonic foraminiferal and calcareous nannoplankton datum levels in the New Zealand Cenozoic: Plankt. Conf., Second Proc. In Farinacci, A. (Ed.), Roma 1970 (Tecnoscienza), p. 649-657.

Lawrence, C.R., 1966. Cenozoic stratigraphy and structure of the Mallee Region, Victoria: Proc. Roy. Soc. Victoria, n. ser., v. 79, p. 517-553.

Lillie, A.R. and Brothers, R.N., 1970. The geology of New Caledonia: New Zealand J. Geol. Geophys., v. 13, p. 145183.

Lindsay, J.M. and Bonnett, J.E., 1973. Tertiary stratigraphy of three deep pores in the Waikerie area of the Murray Basin: Geol. Surv. South Australia, Rep. Invest. 38.

Lindsay, J.M. and Giles, S.D., 1973. The Lepidocyclina zone in Morgan Limestone, along the Murray River, South Australia: Geol. Surv. South Australia Quart Geol. Notes 45 , p. $1-7$.

Lowry, D.C., 1970. Geology of the western Australian part of the Eucla Basin: Geol. Surv. Western Australia Bull. 122.

Ludbrook, N.H., 1961. Stratigraphy of the Murray Basin in South Australia: Geol. Surv. South Australia Bull. 36.

Ludbrook, N.H. and Linsay, J.M., 1967. Tertiary foraminiferal zones in South Australia: Proc. First Internat. Conf. Plankt. Microfossils, v. 2, p. 366-374.

Oppel, T.W., 1970. Exploration of the southwest flank of the Papuan Basin: APEA J., v. 10, p. 62-69.

Palmieri, V., 1971. Tertiary subsurface biostratigraphy of the Capricorn Basin: Geol. Surv. Queensland Rept. 52, p. 1-18.

Parkin, L.W. (Ed.), 1969. Handbook of South Australian geology: Geol. Survey South Australia, Adelaide.

Rodda, P., 1967. Outline of the geology of Viti Levu: New Zealand J. Geol. Geophys., v. 10, p. 1260-1273.

Stevens, G.R. and Suggate, R.P., in press. Atlas of paleogeographic maps. In Suggate, R.P. et al., The Geology of New Zealand: Wellington (N.Z. Govt. Printer).

Taylor, D.J., 1971. Foraminifera and the Cretaceous and Tertiary depositional history in the Otway Basin in Victoria: Spec. Bull. Geol. Surv. S. Australia, Victoria, p. 217-233.

Thompson, J.E., 1967. A geological history of eastern New Guinea: APEA J., v. 7, p. 83-93.

Warris, B.J., 1973. Plate tectonics and the evolution of the Timor Sea, Northwest Australia: APEA J., v. 13, p. 13-18.

Paleocirculation (Bottom Waters)

Barker, P.F., 1970. Plate tectonics of the Scotia Sea region: Nature, v. 228, p. 1293-1296.

Berger, W.H., 1970. Biogenous deep-sea sediments: Fractionation by deep-sea circulation: Geol. Soc. Am. Bull., v. 81, p. 1385-1402.

Conolly, J.R. and Payne, R.R., 1972. Sedimentary patterns within a continent-mid-oceanic ridge-continent profile: Indian Ocean south of Australia: Antarctic Res. Ser. 19 (Antarctic Oceanology II, The Australian-New Zealand Sector), p. 295-315.

Edmond, J.M., Chung, Y., and Sclater, J.G., 1971. Pacific Bottom Water: Penetration east around Hawaii: J. Geophys. Res., v. 76, p. 8089-8097.
Edwards, A.R., 1973. Southwest pacific regional unconformities encountered during Leg 21. In Burns, R.E., Andrews, J.E., et al., Initial Reports of the Deep Sea Drilling Project, Volume 21: Washington (U.S. Government Printing Office), p. 701720.

Gill, A.E. and Bryan, K., 1971. Effects of geometry on the circulation of a three-dimensional southern-hemisphere ocean model: Deep-Sea Res., v. 18, p. 685-721.

Gilmour, A.E., 1973. Temperature observations in the TongaKermadec Trench: Oceanography of the South Pacific 1972, Fraser, R, (Ed.), Wellington (New Zealand National Commission for UNESCO), p. 25-34.

Goodell, H.G., Meylan, M.A., and Grant, B., 1971. Ferromanganese deposits of the South Pacific Ocean, Drake Passage and Scotia Sea: Antarctic Res. Ser. 15 (Antarctic Oceanology I), p. 27-92.

Goodell, H.G. and Watkins, N.D., 1968. The paleomagnetic stratigraphy of the Southern Ocean: $20^{\circ}$ west to $160^{\circ}$ east longitude: Deep-Sea Res., v. 15, p. 89-112.

Gordon, A.L., 1966. Potential temperature, oxygen and circulation of bottom water in the Southern Ocean: Deep-Sea Res., v. 13, p. $1125-1138$.

1972. On the interaction of the Antarctic Circumpoiar Current and the Macquarie Ridge: Antarctic Res. Ser. 19 (Antarctic Oceanology II: The Australian-New Zealand Sector), p. 71-78.

1973. Spreading of Antarctic bottom waters, 2. In stuaies in physical oceanography-A tribute to Georg Wüst on his 80th birthday: New York (Gordon and Breach), v. 2, p. 1-17.

Gordon, A.L. and Tchernia, P., 1972. Waters of the continental margin off Adelie coast, Antarctica: Antarctic Res. Ser. 19 (Antarctic Oceanology II: The Australian-New Zealand Sector), p. 59-69.

Hollister, C.D. and Heezen, B.C., 1966. Ocean bottom currents: In Fairbridge, R.W. (Ed.), The Encyclopedia of oceanography: New York (Van Nostrand Reinhold Company), p. 576-583.

Johnson, D.A., Hollister, C.D., and Lonsdale, P.F., 1972. Carbonate sedimentation and abyssal circulation in the Samoan Passage: Geol. Soc. Am. Abstracts with Programs, v. 4 , p. 554 .

Kennett, J.P., Houtz, R.E., et al., 1975. Initial Reports of the Deep Sea Drilling Project, Volume 29: Washington (U.S. Government Printing Office).

Laird, N.P. and Ryan, T.V., 1969. Bottom current measurements in the Tasman Sea: J. Geophys. Res., v. 74, p. $5433-5438$.

MacDonald, K.C. and Hollister, C.D., 1973. Near-bottom thermocline in the Samoan Passage, West Equatorial Pacific: Nature, v. 243, p. 461-462.

Warren, B.A., 1973. Transpacific hydrograpic sections at lats $43^{\circ} \mathrm{S}$ and $28^{\circ} \mathrm{S}$ : The Scorpio Expedition-II: Deep water: Deep-Sea Res., v. 20, p. 9-38.

Watkins, N.D. and Kennett, J.P., 1972. Regional sedimentary disconformities and upper Cenozoic changes in bottom water velocities between Australasia and Antarctica: Antarctic Res. Ser. 19 (Antarctic Oceanology II, The Australian-New Zealand Sector), p. 273-293.

\section{Paleocirculation (Surface Waters)}

Bandy, O.L. and Casey, R.E., 1973. Reflector horizons and paleobathymetric history, eastern Panama: Geol. Soc. Am. Bull., v. 84, p. 3081-3086.

Burling, R.W., 1961. Hydrology of circumpolar waters south of New Zealand: New Zealand Dept. Sci, Industr. Res. Bull. 143. 
Burns, R.E., Andrews, J.E., Initial Reports of the Deep Sea Drilling Project, Volume 21: Washington (U.S. Government Printing Office).

Gotdon, A.L., 1967. Structure of Antarctic waters between $20^{\circ} \mathrm{W}$ and $170^{\circ} \mathrm{W}$ : Am. Geogr. Soc. Antarctic Map Folio 6. 1971. Oceanography of Antarctic waters: Antarctic Res. Ser. 15 (Antarctic Oceanology I), p. 169-203. , 1972. Introduction: Physical oceanography of the southeast Indian Ocean: Antarctic Res. Ser. 19 (Antarctic Oceanology II: The Australian-New Zealand Sector), p. 39.

1973. Physical oceanography: Antarctic J. U.S., v. 8, p. 61-69.

Heath, R.A., 1973. Present knowledge of the oceanic circulation and hydrology around New Zealand: Tuatara, v. 20, p. $125-140$.

Houtman, T.J., 1967. Water masses and fronts in the Southern Ocean South of New Zealand: New Zealand Dept. Sci. Industr. Res. Bull. 174, p. 40.

Kennett, J.P., Houtz, R.E., et al., 1975. Initial Reports of the Deep Sea Drilling Project, Volume 29: Washington (U.S. Government Printing Office).
Knox, G.A., 1970. Biological oceanography of the South Pacific. In Wooster, W.S. (Ed.), Scientific exploration of the South Pacific: Washington (National Academy of Sciences), p. 155-182.

Stanton, B.R., 1969. Hydrological observations across the tropical convergence north of New Zealand: New Zealand J. Mar. Freshwat. Res., v. 3, p. 124-146.

Sverdrup, H.U., Johnston, M.W., and Fleming, R.H., 1942. The oceans. Their physics, chemistry and general biology: New York (Prentice-Hall Inc.).

Tjia, H.D., 1966. Java Sea. In Fairbridge, R.W. (Ed.), The Encyclopedia of Oceanography: New York (Van Nostrand Reinhold Company), p. 424-429.

Vella, P., 1973. Ocean paleotemperatures and oscillations of the Subtropical Convergence zone on the eastern side of New Zealand. In Fraser, R. (Ed.), Oceanography of the South Pacific 1972: Wellington (New Zealand National Commission for UNESCO), p. 315-318.

Zillman, J.W., 1972. Solar radiation and sea-air interaction south of Australia: Antarctic Res. Ser. 19 (Antarctic Oceanology II, The Australian-New Zealand Sector), p. 1140. 